\title{
Comparative Volcanology and Emplacement Styles of the Star and Orion South Kimberlites, Fort à la Corne, Canada
}

\author{
B.A. Kjarsgaard ${ }^{1}$, S. Harvey ${ }^{2}$, P. Du Plessis ${ }^{2}$, and M. McClintock ${ }^{3}$ \\ ${ }^{1}$ Geological Survey of Canada, 601 Booth Street, Ottawa, Ontario, Canada, K1A OE8 \\ ${ }^{2}$ Shore Gold Inc., 300-224 $4^{\text {th }}$ Avenue South, Saskatoon, Saskatchewan, Canada, S7K 5M5 \\ ${ }^{3}$ Volcanic Solutions Ltd., 20 Moray Place, Dunedin 9013, New Zealand,
}

\section{Introduction}

A wide variety of primary pyroclastic, volcaniclastic and resedimented volcaniclastic deposits derived from multiple kimberlite eruptions are exceptionally well preserved at both the Star and Orion South (140/141) kimberlite bodies in the Fort à la Corne field in central Saskatchewan. Both of these complexes formed due to episodic kimberlite volcanism punctuated by periods of volcanic quiescence, erosion, and sedimentary deposition within the Western Canadian Sedimentary Basin. The Star and Orion South kimberlite complexes erupted into deltaic coastal plain/transitional estuarine (Manville Group) and shallow marine (Lower Colorado Group) environments (Fig. 1). At Star, at least six distinct kimberlite phases erupted over 3 to $4 \mathrm{~m} . \mathrm{y}$. from ca. $104 \mathrm{Ma}$ (Cantuar Formation equivalent age) to ca. $101 \mathrm{Ma}$ (Joli Fou Formation equivalent age; Zonneveld et al., 2004; Harvey et al., 2006). At Orion South, eight distinct kimberlite phases erupted over 6 to $7 \mathrm{~m}$.y. from ca. $106 \mathrm{Ma}$ (Cantuar Formation equivalent age) to ca. $99 \mathrm{Ma}$ (Viking Formation equivalent age; Kjarsgaard et al., 2006). Detailed core logging, geochemistry, geophysics, chronostratigraphy, and petrography was undertaken on a data set consisting of core holes from $100 \mathrm{~m}$ grid drilling (Star $=266$ core holes, plus $3 \mathrm{~km}$ of drifts; Orion South $=131$ core holes) to define distinct eruptive phases. The individual kimberlite eruptive phases are recognized on the basis of a variety of criteria including bedforms, bedding thickness and type; measured olivine, juvenile lapilli and country rock clast size, type, and abundance; amount and nature of matrix material; indicator mineral type, size, and abundance; and whole-rock geochemistry. This unique and objective data set was utilized to understand the volcanology and emplacement history of the Star and Orion South kimberlite complexes.

\section{Star kimberlite}

The central and southern part of the Star kimberlite complex contains the oldest eruptives (Cantuar age; CK-S), consisting of coarse-grained clast-supported olivine crystal tuff and very coarse-grained kimberlite breccia that form sheet-like deposits $<40 \mathrm{~m}$ in thickness. In contrast, to the north are three slightly younger intra-Cantuar kimberlite sheets $(\mathrm{CK}-\mathrm{N})$ that consist of medium-grained matrix-supported olivine and lapilli tuffs. Beds are typically 1 to $5 \mathrm{~m}$ thick. Cr-diopside grains (1-4 mm) are ubiquitous in Cantuar-age kimberlites and mantle xenoliths are common. The Cantuar kimberlites are interpreted as subaerial pyroclastic fall deposited conformably on the Cantuar delta plain. The sheet-like geometry of these kimberlites is related to conformable deposition on the delta plain (lower surface) coupled with fluvio-deltaic erosional processes on the upper surface. Evidence for the latter process is found in reworked trough cross-bedded kimberlite beds in the Cantuar Formation siliciclastic rocks.

The next pulse of kimberlite magma formed two spatially restricted ( $\sim 75 \mathrm{~m}$ diameter) feeder vents in the southeast part of the Star body that cross-cut older CK-S kimberlite sheets. The feeder vents are bounded by Cantuar Formation siliciclastic rocks and at depth by Devonian carbonate sequences (Harvey et al., 2006). These vents do not flare at the Devonian-Cretaceous unconformity.

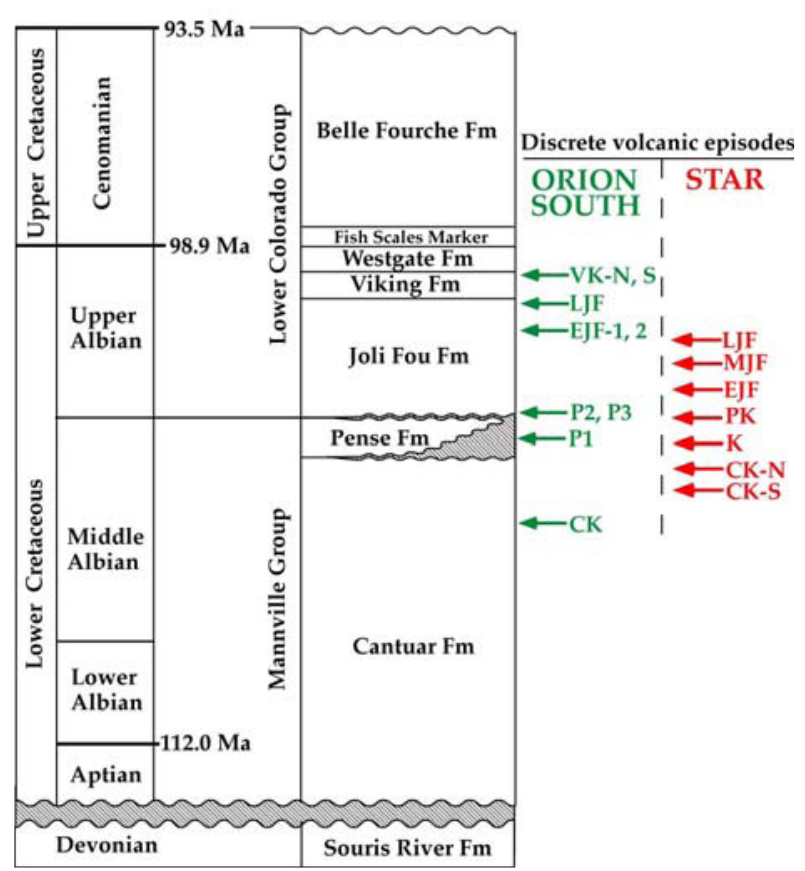

Fig. 1 Stratigraphic position of kimberlite eruption episodes at the Star and Orion South kimberlite complexes. Cretaceous host rock stratigraphic section after Kjarsgaard (1995). 
An areally limited ejecta apron of medium- to coarsegrained, clast-supported kimberlite lapilli tuffs with bed thicknesses of 4 to $40 \mathrm{~m}$ surround the twin vents. The age of these subaerial eruptions is constrained to be very late Cantuar in age (or younger), but older than the lower Joli Fou Formation (i.e. possible Pense equivalent in age). Subsequent Pense-age kimberlite (PK) deposits are found in the central and northern part of the Star kimberlite body. Maximum thickness of PK is approximately $50 \mathrm{~m}$. In the east, these kimberlites lie directly on Pense Formation bioturbated sandstone or Pense Formation mudstone (Zonneveld et al., 2004). The PK is clast supported, with very coarse-grained varieties consisting of close-packed 0.5 to $7 \mathrm{~cm}$ olivine macrocrysts and olivinecored juvenile lapilli, and common ilmenite megacrysts and micro-peridotite xenoliths. Finer grained varieties also consist of subequal olivine and juvenile lapilli. Cross-bedded, well sorted, fine- to medium-grained olivine sandstone is also characteristic of this unit. Overall, the features of the Pense kimberlites and their reworked equivalents are consistent with subaerial eruptions accompanied by deposition (and reworking) in a shoreface to marginal marine environment.

The most voluminous deposits at the Star kimberlite are Early Joli Fou (EJF) equivalent in age. Initial shallow marine subaqueous volcanism is recorded by fine- to medium-grained sub-aqueous density current deposits that conformably lie on lower Joli Fou Formation glauconitic mudstone. Subsequent activity deposited coarseto very coarse-grained clast-supported olivine-rich and juvenile lapilli-poor crystal tuff and breccia from mostly subaerial phreatomagmatic density currents. These density currents scoured and eroded Joli Fou and Cantuar Formation mudstone and siliciclastic sequences, and formed four distinct tongues of thicker and coarser material that radiate away from the EJF vent. Large basement crustal xenoliths are typically imbricated in the kimberlite breccia deposits. Peridotite and eclogite xenoliths and xenocryts are often observed in EJF kimberlite deposits. Continued EJF phreatomagmatic volcanism formed a tuff ring (height $44 \mathrm{~m}$; diameter $\sim 400 \mathrm{~m}$ ) and thinner distal deposits beyond the tuff ring, as shown in Figure 2. EJF kimberlite deposits typically form well bedded (1-5 m thick, rarely to $15 \mathrm{~m}$ ) fining-up couplets, with breccia bases overlain by xenolith-poor tuff.

The younger Mid Joli Fou (MJF) kimberlite feeder vent pierced the west side of the EJF tuff ring, filled the open EJF crater, and formed proximal clast-supported massive to poorly bedded, coarse- to medium-grained fall and flow deposits. More distal deposits are matrix supported and predominantly massive. The youngest kimberlite eruptive event, referred to as the Late Joli Fou (LJF) kimberlite, is confined to the northern part of the Star kimberlite complex and forms a thin veneer $(<12$ m thick) on older EJF and MJF kimberlite deposits. The LJF kimberlite is matrix supported, fine grained, massive, and contains ubiquitous

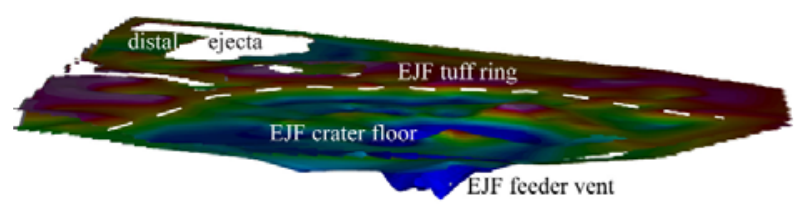

Fig. 2. Three-dimensional contoured upper and lower surfaces for the Early Joli Fou eruptive phase at the Star kimberlite, viewed from west-southwest. Note the positive relief of the tuff ring (red), thinner distal ejecta beds, and the crater floor depression (blue), as well as the flared underlying feeder vent.

0.5 to $50 \mathrm{~mm}$ shale clasts. The relationship between the MJF and LJF kimberlites is ambiguous. One possibility is that the LJF represents a fine-grained remobilized part of the MJF that slumped or flowed into the marginal marine sedimentary environment and incorporated poorly consolidated mudstone material as it did so. All the Star kimberlite deposits are capped by kimberlitic debris flows, marine reworked kimberlite, and marine shale and siltstone sequences of variable $(15-35 \mathrm{~m})$ thickness, which has preserved the overall geometry and architecture of the Star kimberlite complex.

\section{Orion South kimberlite}

At Orion South, the oldest kimberlites are Cantuar age (CK, ca. $106 \mathrm{Ma}, \mathrm{U}-\mathrm{Pb}$ perovskite; Kjarsgaard et al., 2006) medium- to coarse-grained, clast-supported olivine crystal tuffs with normal graded beds (typically $0.5-5 \mathrm{~m}$ thick). These rocks are interpreted to represent subaerial fall deposits and their fluvially reworked equivalents. Although CK erupted through nonlithified Cantuar Formation siliciclastic rocks, the vent is areally restricted ( $<200 \mathrm{~m}$ diameter). Preserved distribution of CK is approximately $0.6 \mathrm{~km}$ radius around the feeder vent.

A younger, Pense-age (P1) kimberlite consists of medium-grained olivine and lapilli tuffs that form a thin but extensive $(1.5 \times 2 \mathrm{~km})$ sheet that is interpreted as variably reworked medial-distal fall deposits. The core of Orion South is dominated by a tuff cone (Fig. 3; preserved height $90 \mathrm{~m}$; diameter $900 \mathrm{~m}$ ) made up of massive- to poorly stratified, medium-grained, matrixsupported, late Pense-age (P2) kimberlite (ca. 104 Ma,

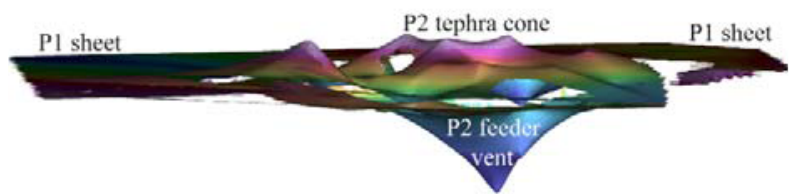

Fig. 3 Three-dimensional contoured upper and lower surfaces for the P1 (sheet) and P2 (tephra cone) eruptive events at the Orion South kimberlite complex, viewed from the south. Note the very deep, wide, and flared P2 feeder vent underlying the P2 tepra cone, which has cut through the older P1 eruptive sheet. Open areas in the P2 upper and lower surfaces represent younger (EJF-1, 2, LJF) cross-cutting eruptive events. 
$\mathrm{U}-\mathrm{Pb}$ perovskite; Kjarsgaard et al., 2006). These deposits are interpreted to record deposition by rapid fallout from tephra jets and from flows derived from 'wet' phreatomagmatic eruptions. Intercalated with P2 deposits are medium-grained, clast-supported olivine tuff (P3 kimberlite) from drier eruptions, suggesting variable water ingress to the $\mathrm{P} 2$ vent. The underlying wide and flared P2 vent was excavated down into the Devonian carbonate sequences during the initial stages of the eruption. The phreatomagmatic nature of the $\mathrm{P} 2$ eruptive sequence is consistent with the shoreface/marginal marine paleodepositional environment of the Pense Formation. Further evidence for significant P2 tuff cone paleo-relief are cone marginal, marine reworked olivine sandstone and numerous slump deposits (up to $15 \mathrm{~m}$ thick) observed above lower Joli Fou Formation shale, up to $300 \mathrm{~m}$ away from the tuff cone margin.

After a period of Joli Fou Formation shale deposition ( $\sim 25 \mathrm{~m}$ in thickness), EJF-age kimberlite was erupted from two separate vents (EJF-1, EJF-2) at ca. 99.4 Ma (U-Pb perovskite; Kjarsgaard et al., 2006) that pierced through the P2 tuff cone deposits. Initial EJF volcanic sequences consist of massive breccia beds (single beds 3-20 m thick) containing large (up to $5 \mathrm{~m}$ ) P2 clasts and abundant basement xenoliths, and common mantle xenoliths and xenocrysts. These rocks are interpreted as deposits from debris flows and pyroclastic flows. Subsequent EJF kimberlite volcanism produced very coarse- to coarse-grained clast-supported olivine-rich and juvenile lapilli-poor deposits that are massive to normally graded and well sorted. These units are interpreted to record deposition from phreatomagmatic eruption-fed density currents. EJF kimberlites are overlain by upper Joli Fou Formation shale units, that in turn underlie late Joli Fou (LJF) age kimberlite. The LJF feeder vent pierces the P2 tuff cone and mantling EJF kimberlite deposits and forms an areally restricted feeder vent, with medial and distal deposits covering most of the Orion South complex as a thin $(<15 \mathrm{~m})$ sheet. The LJF kimberlite is characterized by massive, fine- to very fine-grained, olivine-rich, clast-supported deposits inferred to have formed during subaqueous to emergent eruptions. The youngest kimberlites are Viking (VK) age, thinly bedded, medium-grained clast-supported, juvenile lapilli-rich deposits and marine reworked equivalents, erupted from two separate vents (VK-N and VK-S). VK were conformably deposited on shoreface olivine sandstone (and minor shale) and are interpreted as subaerial pyroclastic fall deposits, consistent with low-stand conditions regionally during Viking time. These deposits are conformably overlain by shale of the Westgate Formation, which blankets and preserves the overall geometry and architecture of the Orion South kimberlite complex.
Seven feeder vents (CK, P2, EJF-1, EJF-2, LJF, VK-N, and VK-S), which are the sources of the seven distinct episodic eruptive packages identified here, have been located within the Orion South complex. In plan view, they all lie on a coincident $305^{\circ}$ azimuth. Given that a significant volume of the kimberlite at Orion South records phreatomagmatic volcanic activity (P2, EJF-1, EJF-2, LJF), consistent with their shoreface to marginal marine setting, it is of note that only P2 has a wide, flared feeder vent, in contrast to the areally restricted feeder vents for EJF-1, EJF-2, and LJF. This is related to the unconsolidated nature of the Cantuar Formation siliciclastic units that form the host rocks for the P2 vent, versus the relatively consolidated nature of the P2 tuff cone deposits that formed the host rocks for the EJF-1, EJF-2, and LJF vents, coupled with reduced water ingress into these vents due to P2 deposits having formed an emergent tephra cone.

\section{Acknowledgements}

The authors would like to thank the Shore Gold Inc. and the Fort à la Corne Joint Venture (Shore Gold Inc. and Newmont Mining) for access to drill core, financial support, and permission to publish.

\section{References}

Harvey, S.E., Kjarsgaard, B.A., Zonneveld, J.P., Heaman, L.M., MacNeil, D., 2006. Volcanology and sedimentology of distinct eruptive phases at the Star kimberlite, Fort à la Corne field, Saskatchewan. Kimberlite Emplacement Workshop, Saskatoon, SK, September 7-12, 2006.

Kjarsgaard, B.A., 1995. Research on kimberlites and applications of diamond exploration techniques in Saskatchewan. In: Richardson, D.G. (Comp.), Investigations Completed by the Saskatchewan Geological Survey and the Geological Survey of Canada under the Geoscience Program of the CanadaSaskatchewan Partnership Agreement on Mineral Development (1990-1995). Geological Survey of Canada, Open File Report 3119, p. 213-226.

Kjarsgaard, B.A., Harvey, S.E., Zonneveld, J.P., Heaman, L., White, D., MacNeil, D., 2006. Volcanic stratigraphy, eruptive sequences and emplacement of the 140/141 kimberlite, Fort à la Corne field, Saskatchewan. Kimberlite Emplacement Workshop, Saskatoon, SK, September 7-12, 2006.

Zonneveld, J-P., Kjarsgaard, B.A., Harvey, S.E., Heaman, L.M., McNeil, D.H., Marcia, K.Y., 2004. Sedimentologic and stratigraphic constraints on emplacement of the Star Kimberlite, east-central Saskatchewan. Lithos, 76, 115-138. 